Jurnal Ilmiah Matematika dan Pendidikan Matematika (JMP)

Vol. 10 No. 2, Desember 2018, hal. 17-30

ISSN (Cetak) : 2085-1456; ISSN (Online) : 2550-0422

\title{
OPTIMASI PROSES PENGERINGAN KOPI \\ DI PABRIK KOPI PTPN XII GUMITIR \\ DENGAN MENGGUNAKAN MASON DRYER
}

\author{
Rusli Hidayat \\ Jurusan Matematika FMIPA Universitas Jember \\ rusli.fmipa@unej.ac.id \\ Firdaus Ubaidillah \\ Jurusan Matematika FMIPA Universitas Jember \\ firdaus_u@yahoo.com \\ Hadi Siswanto \\ Jurusan Matematika FMIPA Universitas Jember \\ hadi.siswanto73195@gmail.com
}

\begin{abstract}
Coffee Processing Plant of the PTPN XII Gumitir is a coffee drying factory that was built in 1910 using a giant barch dryer called Mason Dryer as many as four units, each of which has a capacity of 20 tons, so factory is capable of processing 80 tons for a single simultaneous process. The ambient temperature used is $120^{\circ} \mathrm{C}$ with a residency time of 18 hours and desirable level of reduction in water content of 9\%. To optimize the process, a mathematical model of the process is needed to predict energy use, heat distribution (heat profile in coffe beans) and residency time (heat penetration time required by coffee beans). Existing process models are still limited to models for drying the coffe beans. To optimize the process, a heat transfer temperature from ambient temperature (heating temperature) is neededto enter the Mason Dryer which function as the ambient temperature of the coffee beans at each location/ position of the coffee beans in Mason Dryer. With the discoveryof the model for ambient temperaturewill complement the existing model.
\end{abstract}

\section{Keywords: Optimization of Coffee Drying Process}

\begin{abstract}
ABSTRAK. Pabrik Pengolahan Kopi PTPN XII Gumitir merupakan pabrik pengeringan kopi yang dibangun pada tahun 1910 dengan menggunakan batch dryer raksasa yang disebut dengan Mason Dryer sebanyak empat unit yang masing-masing memiliki kapasitas 20 ton, sehingga pabrik tersebut mampu mengolah 80 ton untuk sekali proses simultan. Temperatur ambient yang digunakan $120^{\circ} \mathrm{C}$ dengan waktu residensi selama 18 jam dan tingkat penurunan kadar air yang diinginkan sebesar 9\%. Untuk melakukan proses optimasi, diperlukan model matematika dari proses tersebut guna memprediksi penggunaan energi, distribusi panas (profil panas dalam biji kopi), dan waktu residensi (waktu penetrasi panas yang diperlukan oleh biji kopi). Model proses yang ada masih terbatas pada model model untuk mengeringkan sebutir biji kopi. Untuk mengoptimalkan proses tersebut diperlukan model perpindahan panas dari temperatur ambient (temperatur
\end{abstract}


pemanas) yang masuk ke dalam Mason Dryer yang berfungsi sebagai temperatur ambient dari biji kopi pada setiap lokasi biji kopi dalam Mason Dryer. Dengan ditemukannya model untuk temperatur ambient akan melengkapi model yang sudah ada.

Kata Kunci: Optimasi Proses Pengeringan Kopi

\section{Pendahuluan}

Kopi merupakan tanaman yang banyak dibudidayakan di negara tropis. Kopi yang populer dibudidayakan di Indonesia adalah kopi robusta dan kopi arabika. Meskipun kopi arabika lebih awal masuki di Indonesia, namun kopi robusta unggul dalam kemampuannya untuk beradaptasi sehingga mudah untuk dibudidayakan (Santoso, 2018).

Proses pengolahan produksi biji kopi robusta mentah (hasil petikan dari pohon) menjadi kopi bubuk bercita rasa tinggi melibatkan serangkaian kegiatan yang berkesinambungan. Tahap pengolahan kopi berturut-turut pemetikan kopi, pengeringan, penyortiran, dan diakhiri dengan beberapa tahap pengelolahan kopi secara sekunder. Salah satu proses pengolahan biji kopi yang sangat penting dan krusial adalah proses pengeringan karena proses tersebut menjadi penentu kualitas biji kopi untuk tahap berikutnya (Hamni, 2014).

Dalam proses pengeringan, kadar air awal biji kopi robusta secara umum yaitu $48.7 \%$ dan kadar air maksimal biji kopi kering menurut SNI yaitu $12.5 \%$ (Agustina, 2016). Proses pengeringan kopi dalam jumlah besar lebih efektif menggunakan alat pengering. Misalnya, dengan alat pengering tray dryer dengan suhu mesin pemanas $60^{\circ} \mathrm{C}$ menunjukkan bahwa semakin tinggi suhu pengeringan semakin cepat mendekati kadar air setimbang yaitu dalam waktu 16 jam (Santoso, 2018). Alat pengering lainnya seperti flex dryer yaitu teknologi yang menggunakan sumber energi matahari untuk pengeringan. Waktu pengeringan menggunakan flex dryer mulai 12,6 jam hingga 22.5 jam tergantung pada suhu pemanasan (De, 2015).

Pabrik Pengolahan Kopi PTP XXVI Gumitir di kawasan Jember Jawa timur merupakan pabrik pengeringan kopi yang dibangun pada tahun 1910 dengan menggunakan batch dryer raksasa sebanyak empat unit yang masingmasing memiliki kapasitas 18 ton, sehingga pabrik tersebut mampu mengolah 72 
ton untuk sekali proses. Untuk melakukan optimalisasi proses, diperlukan model matematika dari proses tersebut guna memprediksi penggunaan energi, distribusi panas (profil panas dalam biji kopi) dan waktu residensi (waktu penetrasi panas yang diperlukan oleh biji kopi). Hal menarik lain adalah waktu pengeringan kopi dari kondisi basah hingga selesai adalah 18 jam. Oleh karena itu, pada kondisi tersebut perlu adanya simulasi untuk mengamati profil biji kopi saat kering optimal. Selain itu, penelitian ini bertujuan untuk menemukan faktor yang mempengaruhi optimasi pada proses pengeringan kopi robusta di Pabrik Pengolahan Kopi PTP XXVI Gumitir di kawasan Jember Jawa timur .

\section{METODE PENELITIAN}

\section{a. Observasi}

Tahap awal penelitian yaitu melakukan observasi ke Pabrik Pengolahan Kopi PTP XXVI Gumitir untuk mengetahui kondisi pengeringan pada mason dryer. Selain itu, dari observasi didapat beberapa data yang digunakan dalam tahap lebih lanjut.

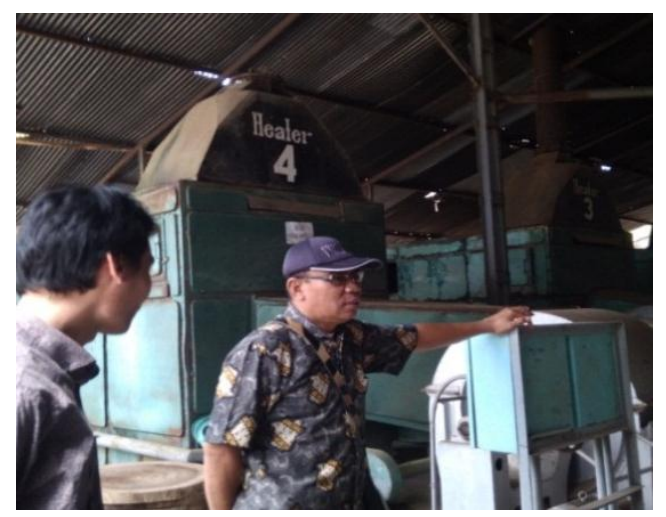

Gambar 1. Salah satu petugas pabrik memberikan penjelasan cara kerja mason dryer.

\section{b. Penentuan Parameter Awal dan Batasan Masalah}

Biji kopi yang baru dipanen pada umumnya berwarna merah dan bentuknya bulat (spheroid) seperti yang tampak pada Gambar 2. 


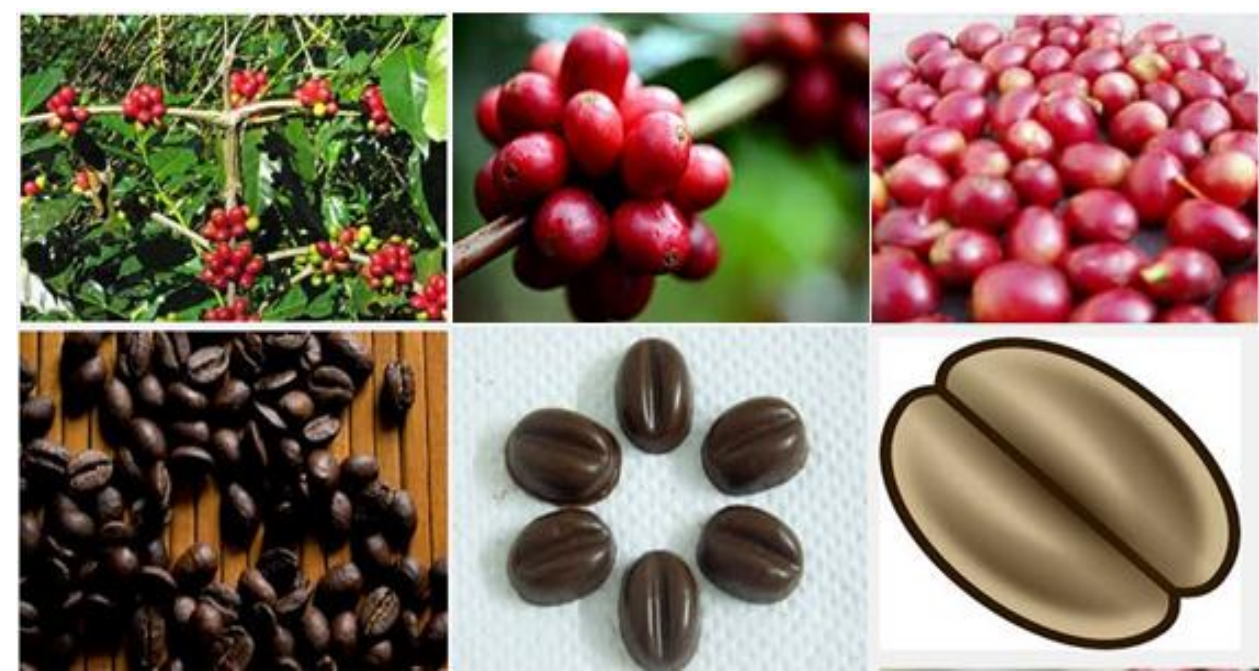

Gambar 2. Gambar biji kopi.

Setelah mengalami pengeringan baik secara alami menggunakan matahari ataupun pengeringan buatan, biji kopi robusta akan menyusut dan berbentuk ellipsoid . Sebelum dimasukkan ke mason dryer, kadar air dalam kopi rata-rata sebesar 48,7 \% hingga kadar air turun sebesar maksimal 12,5\% (sumber). Selanjutnya untuk mengetahui perambatan panas pada kopi dari bagian luar hingga ke bagian inti, diperlukan penampang melintang bagian biji kopi.

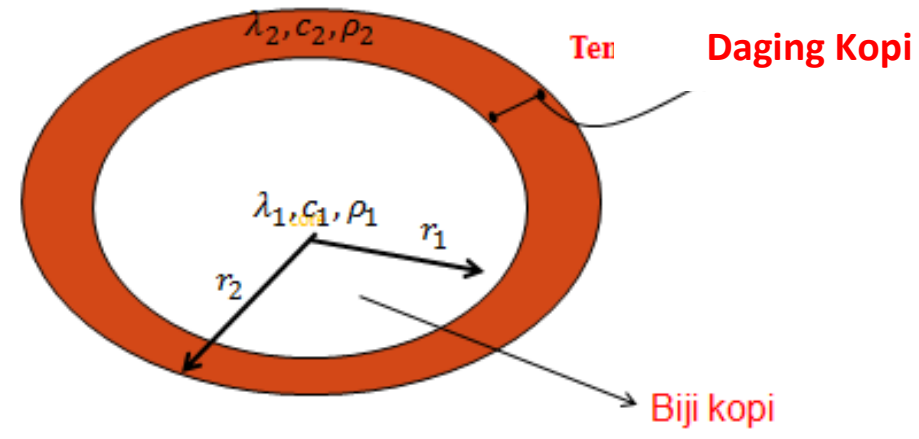

Gambar 3. Gambar biji kopi.

Hidayat (2014) yang merupakan nilai-nilai parameter untuk kopi robusta, yaitu dalam penelitian ini buah kopi diasumsikan berbentuk bola dan terbagi menjadi dua lapisan (layer), yaitu lapisan biji kopi (mesocarp) dan lapisan daging kopi (endocarp). Simbol parameter fisik lapisan biji kopi dan daging kopi yang 
digunakan masing-masing adalah $C_{1}, C_{2}$ (panas spesifik, dalam $\mathrm{J} / \mathrm{kg}^{\circ} \mathrm{C}$ ); $\rho_{1}, \rho_{2}$ (massa jenis, dalam $\mathrm{kg} / \mathrm{m}^{3}$ ); dan $\lambda_{1}, \lambda_{2}$ (konduktivitas panas, dalam $\mathrm{W} / \mathrm{m}^{3{ }^{o}} \mathrm{C}$ ). Nilai semua parameter sifat fisik kopi tersebut diambil dari

$$
C_{1}=2539 ; C_{2}=1713 ; \rho_{1}=1023 ; \rho_{2}=925 ; \lambda_{1}=0.1677 ; \lambda_{2}=0.1713 \text {. }
$$

Dalam hal ini diasumsikan bahwa buah kopi yang dikaji berukuran diameter 1,5 $\mathrm{cm}$ atau $1,5 \cdot 10^{-2} \mathrm{~m}$, dengan rincian biji kopi berjari-jari $0,6 \mathrm{~cm}$ dan ketebalan daging kopi $0,15 \mathrm{~cm}$. Temperatur yang dihantarkan mason dryer ke kopi yaitu $120^{\circ} \mathrm{C}$ dan suhu permukaan buah $25^{\circ} \mathrm{C}$, dengan batasan masalah yaitu panas di dalam mesin terisolasi dan ukuran setiap kopi diasumsikan sama.

\section{c. Menyusun Model Matematika}

Lapisan biji kopi diasumsikan memiliki dua lapisan. Setiap lapisan memiliki sifat fisik yang berbeda. Oleh karena itu, bukan hanya satu model matematika yang bekerja pada sistem pengeringan kopi robusta.

Model matematika yang digunakan mengacu pada model matematika sterilisasi biji kelapa sawit pada mesin pemanas yang memiliki bentuk dan sifat fisik hampir serupa. Walaupun, ukuran kopi lebih kecil dari biji kelapa sawit (Hidayat, 2000).

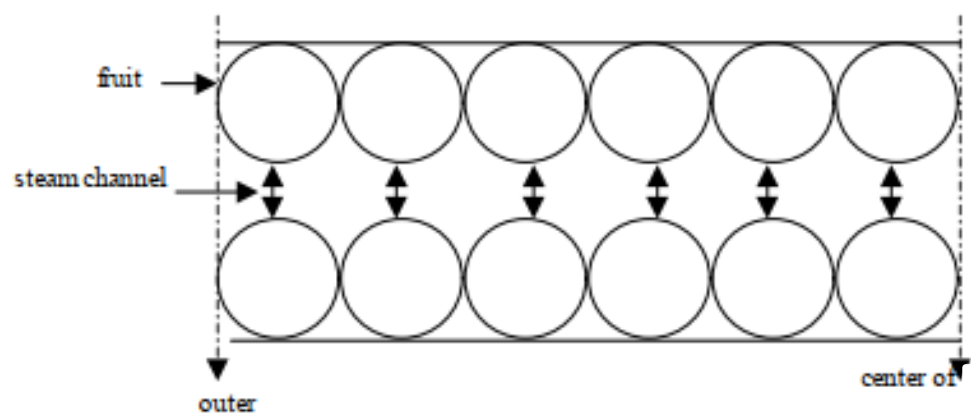

Gambar 4. Skema perambatan panas pada biji Kopi

Biji kopi yang berada pada mason dryer tercampur secara acak. Namun Panas dari pusat pemanas, merambat dari buah satu ke buah lainnya hingga menyebar rata ke seluruhan buah. Oleh karena itu, berdasarkan gambar 4 diasumsikan enam buah berjajar saling mentransfer panas satu dengan lainnya. 
Pada bagian pusat kopi, perubahan suhu terhadap jari-jari selalu nol. Sehingga di titik pusat biji kopi, yaitu di $r=0$ :

$$
\left(\frac{\partial T}{\partial r}\right)_{r=0}=0
$$

Di lapisan biji kopi $0<r<6.10^{-3}$ atau di lapisan daging kopi $6.10^{-3}<r<$ $7,5 \cdot 10^{-3}$ menggunakan persamaan perambatan panas pada bola pejal:

$$
\text { C. } \rho \frac{\partial T}{\partial t}=\frac{1}{r^{2}} \frac{\partial}{\partial r}\left(\lambda r^{2} \frac{\partial T}{\partial r}\right)
$$

Di titik interface (batas lapisan biji dan daging kopi), yaitu di $r=6.10^{-3}$ :

$$
\frac{1}{r^{2}} \frac{\partial}{\partial r}\left(\lambda \cdot r^{2} \frac{\partial T}{\partial r}\right)=\frac{\rho_{1} \cdot C_{1}+\rho_{2} \cdot C_{2}}{2} \frac{\partial T}{\partial t}
$$

Di titik batas luar (antara buah kopi dan lingkungan luar), yaitu di $r=7,5 \cdot 10^{-3}$ :

$$
\lambda_{i}\left\{\frac{\partial T}{\partial r}\right\}_{\text {boundary }}=\frac{\lambda_{o}}{\delta}\left\{\mathrm{T}_{\text {lingkungan }}-\mathrm{T}_{\text {boundary }}\right\}
$$

dengan syarat awal:

$$
T(r, t=0)=T_{a w a l}, 0<r<7,5.10^{-3}
$$

Dari persamaan (1)-(5) akan didiskritisasi menggunakan beda hingga metode $\theta$, dilanjutkan pembuatan program, simulasi, dan tahap akhir yaitu analisis hasil.

\section{HASIL DAN PEMBAHASAN}

\section{a. Diskritisasi}

Dengan menggunakan skema pendiskritan metode $\theta$ (yaitu diambil $\theta=0,75)$, didapatkan bentuk diskrit dari persamaan (1) - (5), yaitu masingmasing pada persamaan (6) - (10). Di titik pusat biji kopi, yaitu di $r=0$ :

$$
\left(1+6 \frac{\lambda}{C \rho} v \theta\right) T_{0}^{k+1}-6 \frac{\lambda}{C \rho} v \theta T_{1}^{k+1}=\left(1-6 \frac{\lambda}{C \rho} v(1-\theta)\right) T_{0}^{k}+6 \frac{\lambda}{C \rho} v(1-\theta) T_{1}^{k},
$$

dengan $v=\frac{\Delta t}{\Delta r^{2}}$. Di titik-titik interior untuk $0<r<6.10^{-3}$ atau $6.10^{-3}<r<$ $7,5 \cdot 10^{-3}$ 


$$
\begin{aligned}
& -\frac{\lambda v \theta\left(j-\frac{1}{2}\right)^{2}}{C \rho\left(j^{2}+\frac{1}{12}\right)} T_{j-1}^{k+1}+\left[1+2 \frac{\lambda v \theta}{C \rho}\left(\frac{\left(j^{2}+\frac{1}{4}\right)}{\left(j^{2}+\frac{1}{12}\right)}\right)\right] T_{j}^{k+1}-\frac{\lambda v \theta\left(j-\frac{1}{2}\right)^{2}}{C \rho\left(j^{2}+\frac{1}{12}\right)} T_{j+1}^{k+1}= \\
& \frac{\lambda v(1-\theta)\left(j-\frac{1}{2}\right)^{2}}{C \rho\left(j^{2}+\frac{1}{12}\right)} T_{j-1}^{k}+\left[1-2 \frac{\lambda v \theta}{C \rho}\left(\frac{\left(j^{2}+\frac{1}{4}\right)}{\left(j^{2}+\frac{1}{12}\right)}\right)\right] T_{j}^{k+1}+\frac{\lambda v(1-\theta)\left(j-\frac{1}{2}\right)^{2}}{C \rho\left(j^{2}+\frac{1}{12}\right)} T_{j+1}^{k+1}
\end{aligned}
$$

Di titik interface (batas lapisan biji dan daging kopi), yaitu di $r=6.10^{-3}$ :

$$
\begin{aligned}
& \frac{v \lambda}{r^{2}\left(\rho_{1} C_{1}+\rho_{2} C_{2}\right)}\left(2 r \theta(\Delta r+r) T_{j+1}^{k+1}+2 r \theta(r-\Delta r) T_{j-1}^{k+1}-4 r^{2} \theta T_{j}^{k+1}\right)-T_{j}^{k+1}= \\
& \frac{v \lambda}{r^{2}\left(\rho_{1} C_{1}+\rho_{2} C_{2}\right)}\left(-(4 r \Delta r(\theta-1))+2 r^{2}(1-\theta)\right) T_{j+1}^{k}-4 r^{2}(\theta-1) T_{j}^{k} \\
& -(4 r \Delta r(\theta-1))+2 r^{2}(1-\theta) T_{j-1}^{k}-T_{j}^{k}
\end{aligned}
$$

Di titik batas luar (antara buah kopi dan lingkungan luar), yaitu di $r=7,5.10^{-3}$ :

$$
\begin{aligned}
-\frac{\theta \cdot k_{3} \cdot \Delta t}{k_{1} \cdot \Delta r_{f}} T_{j-1}^{k+1} & +\left(1+\left[\frac{k_{2}}{k_{1}}+\frac{k_{3}}{k_{1} \cdot \Delta r_{f}}\right] \cdot \Delta t \cdot \theta\right) T_{j}^{k+1} \\
& =-\frac{(1-\theta) \cdot k_{3} \cdot \Delta t}{k_{1} \cdot \Delta r_{f}} T_{j-1}^{k}+\left(1-\left[\frac{k_{2}}{k_{1}}+\frac{k_{3}}{k_{1} \cdot \Delta r_{f}}\right] \cdot \Delta t \cdot(1-\theta)\right) T_{j}^{k}+\frac{k_{2} \cdot \Delta t}{k_{1}} T_{s}
\end{aligned}
$$

di mana nilai dari $k_{1}=N^{2} \frac{\Delta r_{f}}{2}-N^{2} \frac{\Delta r_{f}^{2}}{4}+N^{2} \frac{\Delta r_{f}^{3}}{24}, k_{2}=\frac{\lambda}{c \rho} \frac{(N \cdot \Delta r)^{2} \lambda_{s}}{\lambda_{3} \delta}$, dan $k_{3}=$ $\frac{\lambda}{c \rho}\left(N \cdot \Delta r_{f}-\frac{\Delta r_{f}}{2}\right)^{2}$. Syarat awalnya

$$
T_{j}^{0}=T_{0}
$$

dengan $j$ bergerak dalam radius $0<r<7,5.10^{-3}$.

Dengan sistem pendiskritan sebagaimana pada persamaan (6) - (10), maka untuk grid point $0 \leq j \leq J$, bentuk matriks model pemanasan buah kopi dengan jari-jari $r$ adalah: 


$$
\begin{gathered}
{\left[\begin{array}{ccccccc}
A_{1} & A_{2} & 0 & 0 & \ldots & 0 & 0 \\
\alpha_{1} & \alpha_{2} & \alpha_{3} & 0 & 0 & \ldots & 0 \\
0 & \alpha_{1} & \alpha_{2} & \alpha_{3} & \ldots & \ldots & 0 \\
\ldots & \ldots & \ldots & \ldots & \ldots & \ldots & \ldots \\
\ldots & \ldots & I_{1} & I_{2} & I_{3} & \ldots & \ldots \\
\ldots & \ldots & \ldots & \ldots & \ldots & \ldots & \ldots \\
0 & \ldots & \ldots & \alpha_{1} & \alpha_{2} & \alpha_{3} & 0 \\
0 & 0 & \ldots & \ldots & \alpha_{1} & \alpha_{2} & \alpha_{3} \\
0 & 0 & \ldots & \ldots & 0 & \gamma_{1} & \gamma_{2}
\end{array}\right]\left[\begin{array}{c}
{\left[T_{f}\right]_{0}^{n+1}} \\
{\left[T_{f}\right]_{1}^{n+1}} \\
{\left[T_{f}\right]_{2}^{n+1}} \\
\ldots \\
{\left[T_{f}\right]_{I}^{n+1}} \\
\ldots \\
{\left[T_{f}\right]_{J-2}^{n+1}} \\
{\left[T_{f}\right]_{J-1}^{n+1}} \\
{\left[T_{f}\right]_{J}^{n+1}}
\end{array}\right]} \\
=\left[\begin{array}{ccccccc}
B_{1} & B_{2} & 0 & 0 & \ldots & \ldots & 0 \\
\beta_{1} & \beta_{2} & \beta_{3} & 0 & 0 & \ldots & 0 \\
0 & \beta_{1} & \beta_{2} & \beta_{3} & 0 & \ldots & \ldots \\
\ldots & \ldots & \ldots & \ldots & \ldots & \ldots & \ldots \\
\ldots & \ldots & I_{4} & I_{5} & I_{6} & \ldots & \ldots \\
\ldots & \ldots & \ldots & \ldots & \ldots & \ldots & \ldots \\
0 & \ldots & \ldots & \beta_{1} & \beta_{2} & \beta_{3} & 0 \\
0 & 0 & \ldots & \ldots & \beta_{1} & \beta_{2} & \beta_{3} \\
{\left[T_{f}\right]_{1}^{n}} \\
{\left[T_{f}\right]_{2}^{n}} \\
\ldots \\
{\left[T_{f}\right]_{I}^{n}} \\
\ldots \\
\ldots \\
0 & 0 & \ldots & \ldots & \ldots & \gamma_{3} & \gamma_{4}
\end{array}\right]+\left[\begin{array}{c} 
\\
{\left[T_{f}\right]_{J-1}^{n}} \\
{\left[T_{f}\right]_{J}^{n}}
\end{array}\right]+\left[\begin{array}{c}
0 \\
0 \\
0 \\
\ldots \\
\ldots \\
\ldots \\
0 \\
c_{b} T_{s}
\end{array}\right]
\end{gathered}
$$

dimana $I_{1}, I_{2}, I_{3}, I_{4}, I_{5}$, dan $I_{6}$ adalah komponen matrik pada interface. Nilai komponen matriks ditunjukkan sebagai berikut:

$$
\begin{aligned}
& A_{1}=1+6 \frac{\lambda v \theta}{C \rho}, A_{2}=-6 \frac{\lambda v \theta}{C \rho}, B_{1}=1-6 \frac{\lambda v}{C \rho}(1-\theta), B_{2}=(1-\theta) 6 \frac{\lambda v}{C \rho} \\
& \alpha_{1}=-\frac{\lambda v \theta}{C \rho} \frac{\left(j-\frac{1}{2}\right)^{2}}{\left(j^{2}+\frac{1}{12}\right)}, \alpha_{2}=1+2 \frac{\lambda v \theta}{C \rho} \frac{\left(j^{2}+\frac{1}{4}\right)}{\left(j^{2}+\frac{1}{12}\right)}, \alpha_{3}=-\frac{\lambda v \theta}{C \rho} \frac{\left(j+\frac{1}{2}\right)^{2}}{\left(j^{2}+\frac{1}{12}\right)} \\
& \beta_{1}=\frac{\lambda v(1-\theta)}{C \rho} \frac{\left(j-\frac{1}{2}\right)^{2}}{\left(j^{2}+\frac{1}{12}\right)}, \beta_{2}=1-2 \frac{\lambda v(1-\theta)}{C \rho} \frac{\left(j^{2}+\frac{1}{4}\right)}{\left(j^{2}+\frac{1}{12}\right)}, \beta_{3}=\frac{\lambda v(1-\theta)}{C \rho} \frac{\left(j+\frac{1}{2}\right)^{2}}{\left(j^{2}+\frac{1}{12}\right)} \\
& I_{1}=\frac{v \lambda 2 r \theta(r-\Delta r)}{r^{2}\left(\rho_{1} C_{1}+\rho_{2} C_{2}\right)}, \quad I_{2}=-\frac{v \lambda 4 r^{2} \theta}{r^{2}\left(\rho_{1} C_{1}+\rho_{2} C_{2}\right)}-1 \quad I_{3}=-\frac{v \lambda 2 r \theta(\Delta r+r)}{r^{2}\left(\rho_{1} C_{1}+\rho_{2} C_{2}\right)} \\
& I_{6}=-\frac{v \lambda\left(4 r \Delta r(\theta-1)+2 r^{2}(1-\theta)\right)}{r^{2}\left(\rho_{1} C_{1}+\rho_{2} C_{2}\right)} \quad I_{5}=-\frac{v \lambda 4 r^{2}(\theta-1)}{r^{2}\left(\rho_{1} C_{1}+\rho_{2} C_{2}\right)}-1
\end{aligned}
$$




$$
\begin{aligned}
& I_{4}=-\frac{v \lambda\left(4 r \Delta r(\theta-1)+2 r^{2}(1-\theta)\right)}{r^{2}\left(\rho_{1} C_{1}+\rho_{2} C_{2}\right)} \quad, \quad c_{b}=\frac{k_{2} \Delta t}{k_{1}} \\
& \gamma_{1}=-\frac{\theta k_{3} \Delta t}{k_{1} \Delta r_{f}}, \quad \gamma_{2}=\left(1+\left(\frac{\Delta t k_{2}}{k_{1}}+\frac{\Delta t k_{3}}{k_{1} \Delta r_{f}}\right) \theta\right) \\
& \gamma_{3}=\frac{(1-\theta) k_{3} \Delta t}{k_{1} \Delta r_{f}}, \quad \gamma_{4}=\left(1-\left(\frac{\Delta t k_{2}}{k_{1}}+\frac{\Delta t k_{3}}{k_{1} \Delta r_{f}}\right)(1-\theta)\right)
\end{aligned}
$$

dengan $T_{s=} T_{0}$ merupakan suhu pada pemanas dan $T_{f}=T$ adalah $\mathrm{T}$ buah pada kedalaman tertentu.. Selanjutnya, persamaan (11) akan dicari solusinya menggunakan program matlab yang digunakan untuk simulasi.

\section{b. Waktu dan Penyebaran Panas}

Penyebaran panas pada setiap lapisan biji kopi robusta bisa didapat melalui simulasi program. Nilai parameter awal diantaranya suhu pengeringan $T_{s}=$ $120^{\circ} \mathrm{C}$, suhu buah $T_{f}=25^{\circ} \mathrm{C}, r_{1}=0.65 \mathrm{~cm}, r_{2}=0.75 \mathrm{~cm}$, waktu pemanasan $t=18$ jam, dan parameter lain dari sifat fisik buah kopi. Grafik penyebaran panas pada biji kopi robusta dengan nilai awal disajikan dalam gambar berikut.

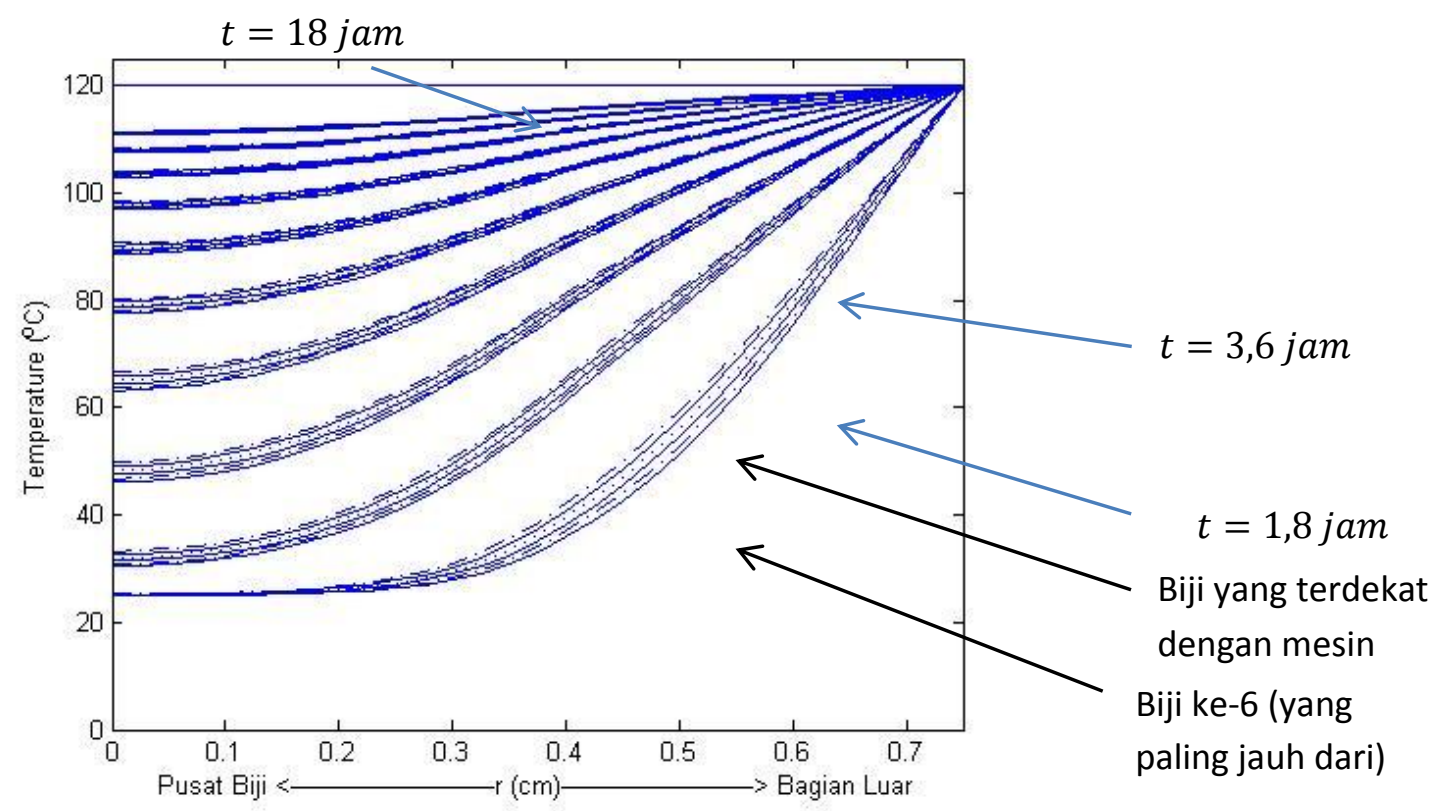

Gambar 5. Grafik Distribusi Panas pada Biji Kopi Robusta dengan Nilai Awal. 
Gambar 5 menunjuk distribusi panas pada biji kopi dalam 18 jam pertama. Seiring dengan berjalannya waktu, suhu di pusat buah kopi meningkat. Walaupun dalam 3 jam pertama peningkatan suhu tidak signifikan. Namun, di waktu berikutnya di atas 5 jam peningkatan suhu di pusat buah mulai tampak. Jika $T_{c 1}$ menyatakan suhu dipusat biji kopi robusta dan $T_{c 2}$ menyatakan suhu pada interface yang menghubungkan biji buah dan daging buah, maka saat $T_{s}=$ $120^{\circ} \mathrm{C}$ dan $t=18$ jam nilai dari $T_{c 1}$ dan $T_{c 2}$ berturut-turut $110,8202167^{\circ} \mathrm{C}$ dan $118,9251682{ }^{\circ} \mathrm{C}$. Berdasarkan hal tersebut, panas pada biji kopi terdistribusi di setiap lapisan.

Berdasarkan asumsi sebelumnya bahwa terdapat 6 buah kopi robusta yang bersentuhan dalam mason dryer, Suhu setiap buah bisa kita simulasikan dari yang terdekat dengan mesin hingga yang paling jauh dengan mesin. Pada gambar 5 saat $t=1.8 \mathrm{jam}$, semua biji awalnya memiliki suhu permukaan yang sama. Namun , pada batas interface suhu keenam buah tersebut mulai terlihat perbedaan. Selain itu, semakin dekat biji kopi robusta dengan pusat panas maka semakin tinggi suhu yang akan terdistribusi dalam biji. Oleh karena itu, perlu adanya pengadukan secara merata sehingga pengeringan optimal.

Tabel 1. Tabel distribusi panas saat $(10-18 \mathrm{jam})$

\begin{tabular}{|c|c|c|c|c|c|c|}
\hline \multirow{2}{*}{$T_{S}$} & \multicolumn{2}{|c|}{$\mathrm{t}=10$} & \multicolumn{2}{c|}{$\mathrm{t}=15$} & \multicolumn{2}{c|}{$\mathrm{t}=18$} \\
\cline { 2 - 7 }$\left({ }^{\circ} \mathrm{C}\right)$ & $T_{c 1}$ & $T_{c 2}$ & $T_{c 1}$ & $T_{c 2}$ & $T_{c 1}$ & $T_{c 2}$ \\
\hline 100 & 72,58623053 & 96,75556166 & 88,04774346 & 98,59968092 & 92,75302541 & 99,1514747 \\
\hline 105 & 75,75849772 & 101,5392477 & 92,25082896 & 103,5063149 & 97,26982322 & 104,0948981 \\
\hline 110 & 78,93076492 & 106,3229337 & 96,45391445 & 108,4129488 & 101,786621 & 109,0383215 \\
\hline 115 & 82,10303212 & 111,1066197 & 100,6569999 & 113,3195828 & 106,3034189 & 113,9817448 \\
\hline 120 & 85,27529931 & 115,8903057 & 104,8600854 & 118,2262168 & 110,8202167 & 118,9251682 \\
\hline 125 & 88,44756651 & 120,6739917 & 109,0631709 & 123,1328507 & 115,3370145 & 123,8685916 \\
\hline 130 & 91,61983371 & 125,4576777 & 113,2662564 & 128,0394847 & 119,8538123 & 128,812015 \\
\hline
\end{tabular}


Tabel 2. Tabel distribusi panas saat (20 dan $25 \mathrm{jam}$ )

\begin{tabular}{|c|c|c|c|c|}
\hline \multirow{2}{*}{$T_{S}$} & \multicolumn{2}{|c|}{$\mathrm{t}=20$} & \multicolumn{2}{c|}{$\mathrm{T}=25$} \\
\cline { 2 - 5 }$\left({ }^{\circ} \mathrm{C}\right)$ & $T_{c 1}$ & $T_{c 2}$ & $T_{c 1}$ & $T_{c 2}$ \\
\hline 100 & 94,80857065 & 99,39221568 & 97,74439781 & 99,73594016 \\
\hline 105 & 99,4624194 & 104,3516902 & 102,5939942 & 104,7183326 \\
\hline 110 & 104,1162682 & 109,3111647 & 107,4435906 & 109,7007251 \\
\hline 115 & 108,7701169 & 114,2706392 & 112,293187 & 114,6831176 \\
\hline 120 & 113,4239657 & 119,2301137 & 117,1427834 & 119,6655101 \\
\hline 125 & 118,0778144 & 124,1895881 & 121,9923798 & 124,6479026 \\
\hline 130 & 122,7316632 & 129,1490626 & 126,8419762 & 129,6302951 \\
\hline
\end{tabular}

Berdasarkan Tabel 1 dan 2 dapat diketahui bahwa semakin besar temperatur pengeringan semakin cepat panas masuk kedalam kopi. Hal demikian juga berlaku terhadap waktu pengeringan karena semakin besar waktu pengeringan semakin cepat panas merambat ke biji kopi. Sehingga untuk mengoptimalkan pengeringan biji kopi, baik mengoptimalkan waktu maupun energi, penentuan waktu pemanasan dan suhu pemanas mason dryer adalah faktor yang sangat penting.

Berikutnya simulasi dengan variasi suhu lingkungan. Variasi suhu lingkungan yaitu $T_{f}=20^{\circ} \mathrm{C}, T_{f}=25^{\circ}, T_{f}=30^{\circ} \mathrm{C}$, dan $T_{f}=35^{\circ} \mathrm{C}$. Suhu pusat kopi masing-masing saat $T_{f}=20^{\circ} \mathrm{C}$ maka $T_{c 1}=110,337^{\circ} \mathrm{C}$, saat $T_{f}=25$ maka $T_{c 1}=110,8202^{\circ} \mathrm{C}$, saat $T_{f}=30^{\circ} \mathrm{C}$ maka $T_{c 1}=111,3034$, dan saat $T_{f}=35^{\circ} \mathrm{C}$ maka $T_{c 1}=111,7866$. Semakin tinggi suhu lingkungan maka semakin tinggi pula suhu pusat kopi saat proses pengeringan. Berdasarkan nilai tersebut dan gambar 6 maka suhu lingkungan berpengaruh dalam proses pengeringan. 


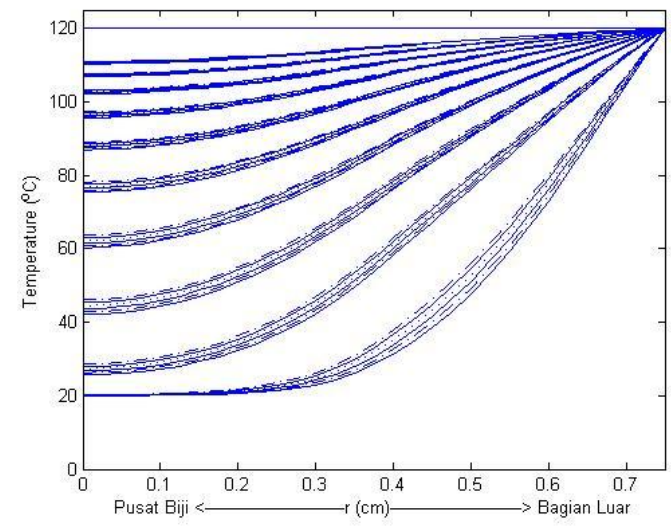

(i)

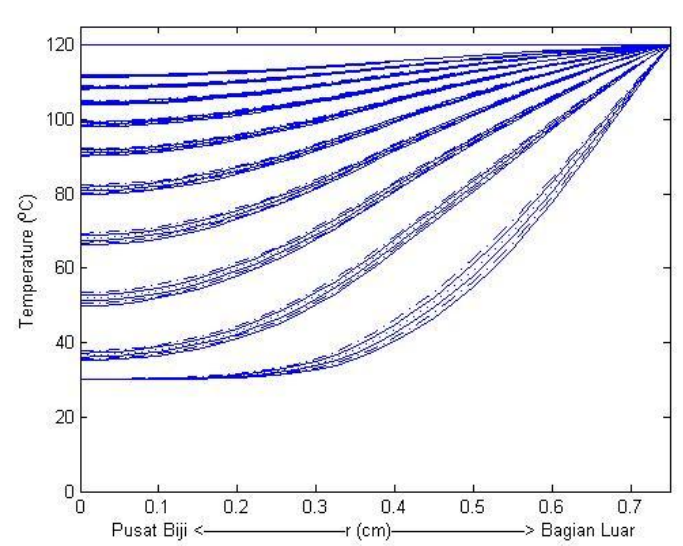

(ii)

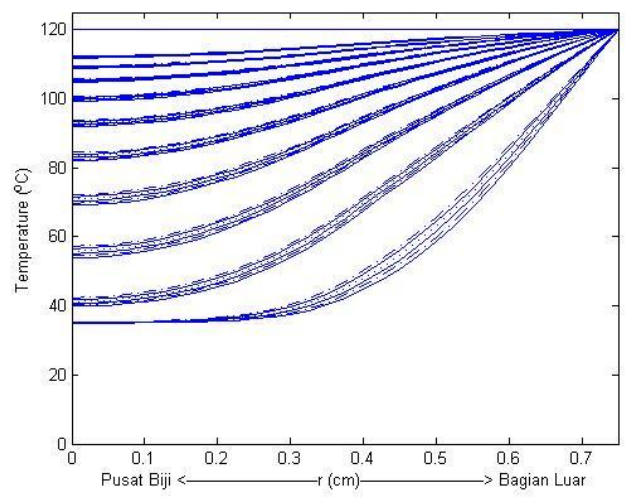

(iii)

Gambar 6. grafik (i) saat $T_{f}=20^{\circ} \mathrm{C}$; (ii) saat $T_{f}=30^{\circ} \mathrm{C}$; dan (iii) saat $T_{f}=35^{\circ} \mathrm{C}$

\section{KESIMPULAN DAN SARAN}

Berdasarkan hasil penelitian yang telah dilakukan dapat disimpulkan bahwa dalam kondisi pengeringan optimal $\left(T_{s}=120^{\circ} \mathrm{C}\right.$ dan $\left.t=18 \mathrm{jam}\right)$ dengan mason dryer dapat diketahui $T_{c 1}$ dan $T_{c 2}$ berturut-turut $110,8202167^{\circ} \mathrm{C}$ dan $118,9251682{ }^{\circ} \mathrm{C}$. Selain itu, beberapa faktor yang mempengaruhi optimalitas pengeringan kopi robusta adalah pengadukan/ pencampuran kopi dalam mason dryer, suhu pemanas, waktu pemanasan, dan suhu lingkunan. Sehingga, Pabrik Pengolahan Kopi PTP XXVI Gumitir dapat mempertimbangkan faktor-faktor 
yang mempengaruhi proses pengeringan kopi agar proses pengeringan biji kopi berjalan lebih optimal dengan mason dryer.

\section{UCAPAN TERIMAKASIH}

Kami ucapkan terimakasih kepada Ketua Lembaga Penelitian Universitas Jember yang telah memberi kesempatan kepada kelompok riset pemodelan matematika untuk melakukan penelitian ini. Tak lupa juga terimakasih sebesarbesarnya kami sampaikan kepada Rektor Universitas Jember atas dukungan finasial yang diberikan.

\section{DAFTAR PUSTAKA}

Agustina, R., d.k.k., Karakteristik Pengeringan Biji Kopi dengan Pengeringan Tipe Bak dengan Sumber Panas Tungku Sekam Kopi dan Kolektor Surya, Jurnal Ilmiah Pertanian Agrotechno, 1(1) (2016), 20-27.

De, J. S., d.k.k., New Technologies for Drying of Coffee, University of Viçosa, Brazil, 1-17, 2015.

Hamni, A., d.k.k., Implementasi Sistem Gasifikasi untuk Pengeringan Biji Kopi, Jurnal Mechanical, 5(1) (2014), 21-25.

Hidayat, R., Modeling Palm Fruit Sterilization In Batch Unit Process, Thesis, Faculty of Mathematical Sciences Twente University, Enschede, Netherlands, 2000.

Hidayat, R., Wijaya, R.D.D., Model Reduksi Kadar Kafein pada Proses Dekafeinasi Biji Kopi, Prosiding Seminar Nasional Matematika, Jurusan Matematika Universitas Jember, 385-394, 2014.

Santoso, D., d.k.k., Model Matematis Pengeringan Lapisan Tipis Biji Kopi Arabika (Coffeae arabica) dan Biji Kopi Robusta (Coffeae), Jurnal Teknologi Pertanian Andalas, 22(1) (2018), 86-95. 
